\title{
IMPLEMENTATION OF INTENSIVE-EXTENSIVE READING STRATEGY TO IMPROVE READING COMPREHENSION
}

\author{
M. Zaini Miftah \\ STAIN Palangka Raya \\ miftahzen@yahoo.com
}

\begin{abstract}
The study is aimed at developing the Intensive-Extensive Reading Strategy (IERS) to improve the students' reading comprehension. The study employed Collaborative Classroom Action Research. The subjects of the study were 32 students of the second semester of English Education Study Program of STAIN Palangka Raya in the 2010/2011 academic year. The data were gained from reading comprehension test, observation, field notes and questionnaire. The findings show that the implementation of IERS with the appropriate procedures developed can improve the students' reading comprehension. It is indicated by the improvements of the percentage of the students achieving the score greater than or equal to $C$ (60-69), and of the percentage of their involvement in the reading activities during the implementation of IERS in Cycles I and II. Consequently, the improvement of the students' reading comprehension can be reached but it should follow the appropriate procedures of the implementation of IERS having been developed.
\end{abstract}

Keywords: Intensive-Extensive Reading Strategy, Reading Comprehension, Improvement.

Reading is an important activity for people, particularly the English Education Study Program students of STAIN Palangka Raya, since every aspect of their life in academic atmosphere involves it. It becomes more important in today's world in which the development in every life aspect occurs very quickly (Burns et al., 1996:5-6). Loucky (1996:1) states that reading as one of the four language skills is a complex and multi-faceted activity in English as a Foreign Language (EFL) context. Therefore, it needs to be developed in EFL teaching as stated by Pearson \& Fielding (1991:816) that spending time on reading in class is important since readers-the students-can get a lot of advantage from the time to apply reading skill and strategies and to acquire new knowledge.

Reading requires word recognition, com- prehension and fluency (Leipzig, 2001). Comprehension is affected by all aspects of the reading process so that word recognition strategy is one of the aspects of reading process (Burns et al., 1996:7). Hence, to understand all types of information in the whole texts, it requires either reading activity or ability to understand the content. Without the ability to understand it, the students are not able to absorb or comprehend a lot of information quickly, accurately and easily.

Despite the importance of reading, throughout the country many English teachers are wrestling with the issue of why students are lack of the skills necessary to comprehend English texts. The majority still has low ability in comprehending English texts. Ability of comprehending a message in the text is the reading goal in a language instruc- 
tion. Comprehending a text message, however, is not easy, particularly in English. Bamford \& Day (2000) claim that in general, EFL reading is a difficult process. Reading test administered on second-semester students of English Education Study Program of STAIN Palangka Raya showed that the percentages of the students' score obtained from the test were $3.13 \%$ (1 student) got score A, 3.13\% (1 student) got score $\mathrm{B}, 25.00 \%$ (8 students) got score C, and $68.75 \%$ (22 students) got score D. These results are considered insufficient since the majority of students were unsuccessful in this course. Only 31.25\% (10 students of the class) achieved the score greater than or equal to $C$ (56-70). They did not yet achieve the target of the study of the Reading Comprehension-II Course at the university. They must at least get score C (56-70) for the majority of students for the Reading Comprehension-II Course success as stated in the guideline of scoring at the university (Tim Penyempurnaan Kurikulum 2004, 2010:38).

Moreover, the researcher has also observed that there are some problems in Reading Class that need to overcome, such as lack of self-confidence in reading English texts, lifeless teaching process, insufficient of reading comprehension. As a result, they were not adequately exposed to English passages unless the teachers provided the texts.

Those problems are caused by a number of factors. The method utilized by the teacher stressed more on product than process. The strategy the teacher employed was more teacher-centered and conventional. In addition, the teacher seldom applied various activities in teaching reading for his students to increase the students' motivation to read. The teacher gave no attention to the learning process but the result of the learning. Also, the teacher was more concerned with the score students obtained rather than process of making students understand.

Regarding the problem to solve, the researcher proposes the Intensive-Extensive
Reading Strategy (IERS). It is a strategy in teaching reading combining some characteristics of intensive and extensive reading activities as well. Its procedure is adapted from Directed Reading Activity (DRA) which is done through some steps-motivating and developing background knowledge, leading to directed reading activities, guiding to skillbuilding activities, providing follow-up activities, and activating enrichment activities (Burns et al., 1996:329).

Reasons for proposing this strategy applied in this study are various, one of which is because the strategy applied in teaching reading combines some characteristics of both intensive and extensive reading activities in which it is able to provide a lot of exposure to improve the students' ability and proficiency in reading. As stated by Sadtono (2007:229), constant exposure to English is the decisive factor for English proficiency. In addition, to build the students' reading comprehension skill, the teachers play an important role in training them to have it. They are the only access of learning English since there is not enough support from the surroundings. Hence, both the students and teachers should take an advantage from the reading class to learn and teach the skills. In this case, intensive reading activities are needed to train the reading skills. Moreover, it is not possible to claim that only intensive reading is sufficient for most ESL/EFL students to learn to read English. They also need a lot of exposures to have reading competence, as Nuttal (1983:168) said that one of the best ways to improve the knowledge of a foreign language is to read it extensively Extensive reading is then necessary for the students to provide exposures in order to improve their understanding of a text. Thus, the way to help the students have reading comprehension ability, the teacher should provide them with both intensive and extensive reading activities.

In accordance with the strength of this strategy, Harmer (2002:210) asserts that in- 
tensive reading instruction is often (but not exclusively) chosen and directed by teachers, and is designed to enable students to develop specific receptive skills. It is usually a classroom-oriented activity in which the students focus on the comprehension of a passage (Brown, 2001:312). Additionally, Nation (2009:25) indicates that intensive reading focuses on comprehension of a particular text and it is useful when reading other texts later on. So, one goal of intensive reading activity may be comprehension of the text.

Carrel \& Carson (1997:49-50) state that extensive reading is reading activity involving rapid reading of large quantities of material or longer reading (e.g., whole book, texts, etc) for general understanding generally focused on the meaning of what is being read rather than on the language. Similarly, Brown (2001:313) indicates that extensive reading is carried out to achieve a general understanding of a usually somewhat longer text such as book, long article, or essay. Moreover, Harmer (2002:210) suggests that extensive reading is an activity that can be applied by teachers to encourage students to choose what they read, and to do so for pleasure and general language improvement. Therefore, extensive reading is the activity of reading a lot of materials for enjoyment, information and language improvement.

Furthermore, Nation (2009:25) adds that when intensive reading activity is used on suitable texts and follows useful principles, this can be a very useful strategy as long as it is only a part of the reading class. To do so, it should be complemented by other languagefocused learning and extensive reading activity for language and fluency developments. Extensive reading activity alone is not sufficient for developing reading skills,-that intensive reading activity is also needed (Loucky, 1996:1-2). Therefore, intensive and extensive reading activities should go together to help readers comprehend a text.

In relation to the study of implement- ing IERS in teaching reading, a few studies had already been carried out. Kara $(\ulcorner\cdots 1)$ investigated the effectiveness of Extensive Reading (it was called ER) on reading development. The result revealed that the strategy had a positive effect on the reading development of the EFL students. The other study was conducted by Argarini (2008) trying to solve the students' problem in reading comprehension using Intensive-Extensive Reading Activity (it was called INEXRA). This strategy offered the solution to unify the two ways (intensive and extensive reading activities) in teaching reading for the sake of the improvement of the students' reading comprehension.

Based on the background of the study, the research problem is: "How can IERS be implemented to improve the students' reading comprehension?" Meanwhile, this study aims at developing IERS to improve the students' reading comprehension. The study focused on developing IERS to solve the problem of how the students get exposed to their reading activities with various activities to increase their motivation in reading English texts by implementing the IERS. Regarding the assessment, this study focused on the process and product assessments.

Meanwhile, since the implementation of IERS in this study was centered on improving the reading comprehension of the second-semester students of English Education Study Program of STAIN Palangka Raya in the 2010/2011 academic year, the objective of teaching reading was based on the existing syllabus at the university. The materials for intensive reading activity were taken from various references such as books written by Mikulecky et al. (1996) and by Muschla (2003), magazines, newspapers, or reading texts downloaded from the internet, while those for extensive reading activity were only taken from various references such as books, magazines, newspapers or reading texts downloaded from the internet. Since the students were 
still in the second semester that tended to be in the low semester, the questions designed to reflect the students' reading ability that need to comprehend were limited to literal and interpretive (inferential) questions.

\section{METHOD}

The study employed Collaborative Classroom Action Research. Both the researcher and his collaborator worked together in cyclic activities (Kemmis \& McTaggart, 1992) - planning, implementing, observing and reflecting to gain the data from the teaching and learning process - which run in two cycles, each of which covered four meetings. The subjects of the study were the second -semester students of English Education Study Program of STAIN Palangka Raya in 2010/2011 academic year. The numbers of subjects were 32 students taking the course of Reading Comprehension II.

In implementing the action, it was based on the planning of developing IERS that was well-prepared. It include the appropriate procedures of implementation of IERS, the lesson plans, the design of research instruments, and the criteria of success. To obtain the students' data on reading comprehension applying IERS, a test was administered. The test was constructed based on some aspects of reading comprehension. It was in the form of short answer questions containing reading text completed with the comprehension questions - literal and inferential. There were two sets of test administered; one was used for the test when Cycle I ended and the rest is used for the test when Cycle II ended. The topics of the tests were selected for the appropriateness in terms of the course syllabus of Reading Comprehension II and students' interest. For each test there were 10 questions covering 5 literal comprehension questions (identifying the students' ability in comprehending the stated main ideas, stated details, stated cause-andeffect relationships, and stated sequences) and 5 inferential comprehension questions (to know the students' ability in comprehending the inferences about main ideas of passages, cause and effect relationships, referents of pronouns, and referents of adverbs, and also included detecting the author's purpose in writing a selection). In analyzing the data, the researcher analyzed them based on two classifications.

The data dealing with the students' reading comprehension achievement were assessed utilizing the scoring rubric for reading comprehension. Their individual score was obtained from the sum of scores gotten from the score for question number 1 up to 10 divided by 20 (maximum score) and then multiplied by 100 (maximum score based on scoring guide at the university). The results of the analysis were then presented quantitatively in the form of number as shown in Table 1. Meanwhile, the data dealing with the students' involvement in the reading class gathered through observation checklist were analyzed quantitatively based on the number of the scale checked by the observer in the observation checklist. The percentage of the students doing the activities was gained from the mean of total students doing the activities divided by the student number of the whole class and then multiplied by 100 . The results of the analysis were next presented quantitatively (Table 2) as well as qualitatively by interpreting the number of percentage gained. In addition, the data gathered through field notes were analyzed and then merely presented descriptively by presenting the description of the teaching and learning process.

The results of all the analyses, furthermore, were employed to decide whether the predetermined criteria of success were met or not. The result of this reflection was then used as the basic consideration to draw a conclusion whether the action was stopped or needed improvement. If the action met the criteria of success, it stopped. Otherwise, the drawbacks were identified for further revised plan and then implemented it in the next cycle. 


\section{FINDINGS AND DISCUSSION}

Based on the research findings, the implementation of IERS can improve the students' reading comprehension. Although all students have not achieved the maximum results, most of their reading comprehension have improved, as shown in the results of the assessment in each cycle (Table 1 and 2).

Regarding the above description, it seems that the students are able to comprehend the text when they do all of the activities provided by the lecturer during the process of the action cycles. Those activities are related to the procedures employed in the reading class that may improve their reading comprehension. The appropriate procedures of the implementation of IERS developed by the lecturer for reading activities involves the application of the reading stages - pre, whilst, and post-reading activities - in which intensive and extensive reading activities can be implemented (Bamford \& Day:2000; Harmer, 2002). The procedure of implementing IERS is adapted from Directed Reading Activity which it is done through some steps: 1) motivating and developing background knowledge, 2) leading to directed reading activities, 3) guiding to skill-building activities, 4) providing follow-up activities, and 5) activating enrichment activities (Burns et al., 1996:329).

In pre-reading activities, it focused on motivating and developing the students' background knowledge. First, the lecturer led the students to a topic by showing pictures through LCD followed by some questions as brainstorming. It is to attract the students' attention on the topic of the text to be discussed by helping them associate it with their own experience (Burns et al., 1996:329). Then he introduced the issue or topic of the students' interest, and told the instructional objectives. In addition, he distributed the handout containing the reading text or story.

In whilst-reading activities, it focused on leading the students to directed reading activities, and on guiding the students to skill- building activities. In leading the students to directed reading activities, first, before reading the story, the lecturer strongly gave a model of how to read comprehensively through skimming, scanning, predicting, summarizing and previewing. As Burns et al. (1996:330) suggested that directed reading generally involves the lecturer asking questions and the students reading to find the answers, or the lecturer asking the students to make predictions and read to confirm or reject them. To do so, he asked the students to read the text silently. While they are reading, he assigned the students to locate difficult words. Then he helped them define the meaning of those words, and explained the content of the text followed by questioning them orally. Moreover, he did modeling those techniques systematically and slowly in order to give them a chance to think about the text.

In guiding the students to skill-building activities, first, the lecturer asked the students to make groups of three based on their interest, and selected a facilitator of each group. The groups had to follow the rules. Second, he asked them to answer several reading comprehension questions based on the provided text. Previously, he clarified some question words, and gave the examples of how to answer the questions. The provided questions were on the basis of some aspects of literal and interpretive reading comprehensions. Then he discussed the answers with the class to aid students' comprehension. Additionally, the lecturer assigned them to search any types of reading text from the newspaper, magazine, book or internet as their home assignment for the following activities. The topic assigned was based on the students' interest. Harmer (2002:210) suggested that teacher should encourage students to choose for themselves what they read and to do so for pleasure and general language improvement. It is extensive reading that have a lot of materials for enjoyment, information and language improvement. 
Post-reading activities provided the students with follow-up activities, and on activating the students to the enrichment activities. As suggested by Bamford \& Day (2000:7-8), because the goal is for students to experience reading, teachers may need to ask students to engage in follow-up activities after reading. In providing the students with follow-up activities, first, the lecturer modeled the students in how to recognize word and main ideas of the text or how to make some comprehension questions and how to answer the questions. Second, he asked them to read different topic of another text from their interest intensively; it was taken from their home assignment. Then he assigned them to make some reading comprehension questions considering some aspects of literal and interpretive reading comprehensions, and assigned to answer them. This activity is designed to lead the students to read the text intensively and train them to identify the stated information and to understand the implied information in the text. Next the lecturer discussed the answers with the class. After that, the lecturer assigned the students to search kinds of texts they were interested in. There must be a wide variety of reading material on a large range of topics, and a chance to allow students to find material they want to read, regardless of their interests (Bamford \& Day, 2000:7-8). Prior the task was given, the lecturer gave a model of how to do the text report individually and in group since they had to report it in the following steps. To do so, he distributed text report form to the students. Then he asked the students to read their texts as many times as possible as their home assignment and to do the text report.

In activating the students to the enrichment activities, the lecturer asked the students to present both their individual and group reports. Individually, he assigned them to read their selected text for some more minutes before the other members of a group. So it needed not only some minutes but also a lot of time to do so. It was aimed at controlling their assignment individually. Next he asked them to make conference to discuss how to make questions and answer them in group, so all members of group became active. By sharing their knowledge with their friends, they are also sharing their responsibility for the answers (Harmer, 2002:213). At the end of presentation time, he asked them to submit their individual text reports. In group, the lecturer assigned all groups to hold an interview to other groups to check their reading comprehension of the text (their home assignments). It was to maximally control each group to do assignment extensively. After that, each group was assigned to hold a discussion in group to decide one of the texts to be reported orally before the class. Then each group presented their text report orally before the class. Finally, the lecturer asked all groups to submit their text reports in written form as written report.

Some other aspects considered that have given a significant contribution to the students' improvement during the reading class particularly when implemented IERS are (1) clear instruction and explanation of doing a model of how to read comprehensively through skimming, scanning, predicting, summarizing and previewing, (2) maximum guidance and control in applying the IERS, (3) the need of visual media related to the topic discussed, (4) the way of grouping in doing the writing task that should be based on the students' interest, not based on the teacher's decision, (5) the need of kind of text based on students' interest, (6) the need of sufficient time when reading text both intensively and extensively, (7) the need of extra treatment individually for those who get problems during the reading class, and (8) the need of review session of understanding level of reading comprehension of both literal and interpretive. 


\section{The Improvement of the Students' Reading Comprehension}

The students' achievement on reading comprehension increased as shown from the improvement of the percentage of the students achieving the score greater than or equal to $C$ (60-69) in Preliminary Study (PS), Cycle I and II as shown in Figure 1.

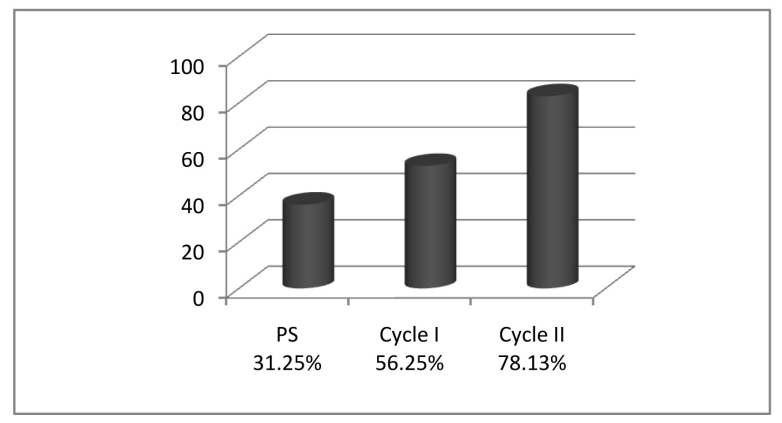

Figure 1. The Improvement of the Percentage of the Students Achieving the Score $\geq C$ (60-69)

Figure 1 shows that the percentage of the students achieving the score greater than or equal to C (60-69) in PS is $31.25 \%$ (10 out of 32 students). It increased enough into $56.25 \%$ (18 students out of 32 students) in Cycle I. Meanwhile, in Cycle II it increased to $78.13 \%$ (25 out of 32 students). This was a slight improvement.

Dealing with the students' involvement in the reading activities during the implementation of IERS in the teaching and learning process, it is shown from the improvement of the percentage of the students' involvement in the reading activities in each cycle. The improvement of their involvement in the reading activities in Cycle I and II is shown in Figure 2.

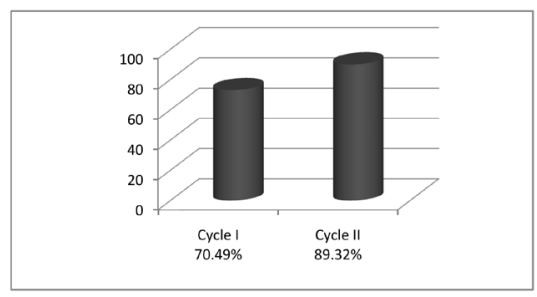

Figure 2. The Improvement of the Students' Involvement in the Reading Activities
Figure 2 shows that in Cycle I some students did not implement all activities seriously, but most of them did. $70.49 \%$ students (23 of the class) -involved in the reading activities. Meanwhile, in Cycle II the students involved in the reading activities increased to $89.32 \%$ students (29 students of the class). They actively involved in the reading activities.

\section{CONCLUSION}

After implementing IERS with the appropriate procedures developed, the students' reading comprehension improves. It is indicated by the improvements of the percentage of the students achieving the score greater than or equal to $C(60-69)$, and of the percentage of their involvement in the reading activities during the implementation of IERS in Cycle I and II (Figure 1 and 2). The success of this study is in Cycle II. So, it needs long time to succeed in this study.

The improvement of the students' reading comprehension can be reached but it should follow the appropriate procedures of the implementation of IERS as follows: (1) leading students to the topic by showing pictures through LCD followed by some questions as brainstorming, (2) introducing the issue or topic and the instructional objectives, (3) distributing handout containing the reading text or story, (4) modeling how to read through skimming, scanning, predicting, summarizing and previewing, (5) asking students to read the text silently and locate difficult words. (6) helping students define the meaning of those words by explaining content of the text through questioning, (8) grouping students into groups of three based on their interest, (9) clarifying some question words and giving examples of how to answer the questions based on some aspects of literal and interpretive reading comprehensions, (10) asking students to answer several reading comprehension questions, (11) discussing the answers with the class, (12) assigning students to search any types of reading text 
from the newspaper, magazine, book or internet as their home assignment, (13) modeling how to recognize word and main ideas of the text or how to make some comprehension questions and answer them, (14) asking students to read different topic of another text from their interest intensively, (15) assigning students to make some reading comprehension questions, and to answer them, (16) discussing the answers with the class, (17) modeling how to do the text report individually and in group by distributing text report form, (18) assigning students to search kind of texts of their interest, (19) asking students to read their texts as many times as possible

\section{REFERENCES}

Artgarini, D. (2008). Improving Students' Reading Comprehension through IntensiveExtensive Reading Activity (INEXRA) at MTs Negeri 3 Surabaya. Unpublished Thesis. Malang: State University of Malang.

Bamford, J., \& Day, R. R. (2000). Extensive Reading in the Second Language Classroom. Cambridge: Cambridge University Press.

Brown, H. D. (2001). Teaching by Principles: An Interactive Approach to Language Pedagogy. $2^{\text {nd }}$ ed. New York: Addison Wesley Longman, Inc.

Burns, P. C., Roe, B. D., \& Ross, E. P. (1996). Teaching Reading in Today's Elementary Schools, $6^{\text {th }}$ ed. Boston: Houghton Mifflin Company.

Carrel, P. L., \& Carson, J. G. (1997). Extensive and Intensive Reading in an EAP Setting, English for Specific Purposes,16, 47-60.

Harmer, J. (2002). The Practice of English Language Teaching, $3^{\text {rd }}$ ed. London: Longman.

Kara, H. B. (2006). The Effects of Extensive Reading on Reading Development. Unpub- as their home assignment and to do the text report, (20) asking students to read their selected text individually for some more minutes before their group, (21) asking students to make conference to discuss how to make questions and answer them in their group, and submit their individual text reports, (22) assigning all groups to hold interview to other groups to check their reading comprehension of the text, (23) assigning each group to hold a discussion to decide one of the texts to be reported orally before the class, (24) asking each group to present their text report orally before the class, and (25) asking all groups to submit their text reports in written form.

lished Dissertation. Konya: Selcuk University.

Kemmis, S. \& McTaggart, R. (1992). The Action Research Planner, $3^{\text {rd }}$ ed. Victoria: Deakin University Press.

Leipzig, D. H. (2001). What is Reading? WETA. (Online). URL: http:/ / www. readingrockets.org/article/352. (Accessed on 2 February 2010).

Loucky, J. P. (1996). Combining Intensive and Extensive Reading Strategies with Cooperative and Communicative Learning Activities. Seinan Women's University. (Online). HTML: http:// www.7.Tiki.ne.jp/-call4all/pdfiles/ jo4-combining.pdf. (Accessed on 2 February 2010).

Mikulecky, B. S. \& Jeffries, L. (1996). More Reading Power: Reading for Pleasure, Comprehension Skills, Thinking Skills, Reading Faster. New York: AddisonWesley Publishing Company, Inc.

Muschla, G. R. (2003). Ready-to-use Reading Proficiency Lessons and Activities, $10^{\text {th }}$ Grade Level. San Fransisco: JosseyBass.

Nation, I. S. P. (2009). Teaching ESL/EFL Read- 
ing and Writing. New York: Routledge.

Nuttal, C. (1983). Teaching Reading Skills in a Foreign Language. London: Heinemann Educational Books Ltd.

Pearson, P. D., \& Fielding, L. (1991). Comprehension Instruction. In R. Barr, M. Kamis, P. Mosenthal, E P. Pearson (Eds.), Handbook of Reading Research (vol.11;pages 815-860). White Plains, NY: Longman.
Sadtono, E. (2007). A Concise History of Teaching English as a Foreign Language in Indonesia. In Yeon Hee Choi \& Spolsky, B. (Eds), English Education in Asia: History and Policies. (pp.205231). Seoul: Asia TEFL.

Tim Penyempurnaan Kurikulum 2004. (2010). Pedoman Akademik dan Kemahasiswaan STAIN Palangka Raya Tahun 2010. Palangka Raya: 
